\title{
At the foot of Mount Olympus: A theory on myth
}

\author{
Flip Schutte (Witbank) ${ }^{1}$ \\ Research Associate: Department of Old Testament Studies \\ University of Pretoria
}

\begin{abstract}
A cult normally develops around myths and rituals. In this article myth as phenomenon will be investigated. Different types and categories of myths will be listed, while research done in the past on myths will also be dealt with. Furthermore, the issue of ritual accompanying the myth will be briefly discussed. This article wants to promote the notion that one does not need any particular worldview, be it mythological, orthodox, fundamentalistic, or biblisistic, to use, understand, and appreciate myths. Even in a postmodern world the value of myths can be appreciated.
\end{abstract}

\section{POINT OF DEPARTURE}

I take it for granted that one can speak of the transcendent in a mythical way. Yet it is helpful to distinguish between myth as a vehicle for communication about the otherworldly, and myth as referring to a mythological worldview. One does not necessarily need a mythological worldview to use, understand, and to appreciate myths. One can appreciate the value of myths even in a postmodern world.

Therefore I do not evaluate myths negatively. I evaluate a positivistic ${ }^{2}$ interpretation of myths negative, especially when modern people cling to a mythical worldview ${ }^{3}$ of biblisistic fundamentalism. We begin this venture into mythology with the story that Crossan used to end the preface of his book The birth of Christianity (see 1998:xi). The story is the famous one taken from Luke 24:13-33.

Two Christians travelled from Jerusalem to Emmaus on Easter Sunday. The risen Jesus joins them on their journey. "But the road to

\footnotetext{
${ }^{1}$ Dr Flip (PJW) Schutte (D Litt et Phil, DTh, PhD) is a research associate of Prof Dr Dirk J Human, Department of Old Testament Studies, Faculty of Theology, University of Pretoria.

${ }^{2}$ When myths are interpreted as objective historical data and facts.

${ }^{3}$ Heaven above, earth, and underworld.
} 
Emmaus is not the road to Damascus. This is an apparition without blinding light or heavenly voice. This is a vision without slow demonstration or immediate recognition. Even when Jesus explains the Scriptures about the suffering and glorification of the Messiah, the travellers do not know who he is. But then they invite the stranger to stay and eat with them. He does not invite them. They invite him ... So he went in to stay with them ... Then their eyes were opened, and they recognized him; and he vanished from their sight ... Resurrected life and risen vision appear as offered shelter and shared meal. Resurrection is not enough. You still need scripture and eucharist, tradition and table, community and justice; otherwise, divine presence remains unrecognized and human eyes remain unopened."

You still need scripture and eucharist, Crossan said. A cult is formed around myths (scripture) and rituals (eucharist). Studying and discussing the question about the mythological worldview and narratives underlying the story and kerygma of Jesus of Nazareth, is not the exclusive prerogative of the scholarly community. The faith community, the institutionalized church and the secular community are discussing it as well, although not everybody is equally willing to face the results and consequences of a critical investigation into myth.

Before one can make an informed conclusion about the foundational myth of the Christ cult, one has to investigate all the options, as well as the phenomenon called myth. What follows is therefore a journey into mythology. I explore the definition, the history of the interpretation of myth, its role in religion, psychology and philosophy, and its connection with rituals. In the end, I hope to indicate that myths are just as important to postmodern man, as it were to our pre-modern ancestors.

\section{MYTH - DOES A PROPER DEFINITION EXIST?}

Mythology is the body of myths of a particular culture. Mythology is also the study and interpretation of such myths. A myth may be broadly defined as a narrative that through many retellings has become an accepted tradition in a society. Usually it is a story about gods or other superhuman beings, or one told to account for a custom, institutions, or natural phenomenon (Gaster 1982:481). When people began to device their myths and worship their gods, they were not seeking to find a literal explanation for natural phenomena. According to Armstrong (1999:11) the symbolic stories, cave paintings and carvings were an attempt to express their wonder and to link this pervasive mystery with their own lives; indeed poets, artists and musicians are often impelled by a similar desire today. Thus, as Kerényi (1976:446) states, every 
view of mythology is a view of man and every theology is at the same time anthropology.

Myths are universal and they occur in almost all cultures. They typically date from a time before the introduction of writing, when they were passed orally from one generation to the next. We are, according to Fontenrose (1959:5) likely to think that, for example, Greek myths were always told as Ovid tells them. They most certainly were not. A myth moving from place to place, passing from one person to another, and from one generation to another, is constantly undergoing change. New versions are formed in every region and age. "A traditional plot, on entering a new region, usually becomes attached to the gods and heroes of that region" (Fontenrose 1959:6). Asclepius, for example, according to Smith (1971:184), inherited from folklore a prodigious death. Epidaurus provided him with a typical birth story and he let Asclepius teach Delphic morality. When he was admitted to Athens, he was associated with the Eleusinian mysteries and became an initiate. The Stoics equated him with the air and neo-Platonism made him the soul of the universe. In the solar theology, he was identified with the sun, the light of men, the savior. In Syria and Palestine, he was identified with the dying and reviving god Eshmun and when the oracles had a revival he gave oracles and mediated those of Hermes.

Myths deal with basic questions about the nature of the world and human experience, and because of their all-encompassing nature, myths can illuminate many aspects of a culture. Ancient peoples used myths to express their sense of the past (cf Stewart 1971:76). According to Mircea Eliade (in Segal 1999:21), myth narrates a sacred history. It relates an event that took part in primordial time. Myth tells how, through the deeds of supernatural beings, a reality came into existence. Myths not only narrate the origin of the world, of animals and plants, but also the primordial events in consequence of which man became what he is today. Therefore, myth makes the present less arbitrary and more tolerate by locating its origin in the distant past. Myths can therefore be characterized (Honko1984:51) as ontological, because they are incorporated and integrated into a coherent view of the world.

For Bultmann and Jonas (cf Segal 1999:24) myth does not explain the world because myth is not about the world. The true subject matter of myth is the place of human beings in the world, and the function of myth is to describe that place, to express man's understanding of himself in the world in which he lives. Therefore, myth must be interpreted existentially.

Most modern historians of religion use the word "myth" as technical term for that literary form which tells about otherworldly things in this-worldly concepts. Thus, myth expresses truth in a hidden or indirect language (Dinkler 
1982:487). Because of this truth, which Frankfort (1946:7) called an unverifiable and metaphysical truth, myth is to be taken seriously. Or as Frankfort (1946:8) summarized the complex character of myth: "Myth is a form of poetry which transcends poetry in that it proclaims a truth; a form of reasoning which transcends reasoning in that it wants to bring about the truth it proclaims; a form of action, of ritual behaviour, which does not find its fulfilment in the act but must proclaim and elaborate a poetic form of truth." In an article, The truth of myth Raffaele Pettazzoni (1984:103; cf Gaster 1984:132133) states the following about the truth of myth:

Their truth has no origin in logic, nor is it of a historical kind; it is above all of a religious and more especially a magical order. The efficacy of the myth for the ends of the cult, the preservation of the world and of life, lies in the magic of the word, in its evocative power, the power of mythos in its oldest sense, of the fa-bula not as "fabulous" narrative but as a secret and potent force ....

For the philosopher, Ernst Cassirer the definition of myth was much broader. He says that: "In non-technical terms it includes not only verbal or written stories but also a type of perception, actions, customs, images, and pictorial representation. Myth is a type of living, feeling and knowing" (see Schultz 2000:32). In defining myth, it thus seems the safest to keep the definition as flexible as possible.

\subsection{Categories of myths}

Although it is difficult to draw rigid distinctions among various types of traditional tales, it is useful to categorize them. The three most common types of tales are sagas, legends, and folktales.

When a tale is based on a great historical or supposedly historical event, it is generally known as a saga. Despite a saga's basis in very distant historical events, its dramatic structure and characters is the product of storytellers' imaginations. Famous sagas include the Greek story of the Trojan War. The function of myth in something like religious sagas is to be a vehicle for the word and to give the story eternal value and pertinence. Take for example the exodus narrative, as Gaster (1982:486) suggests. The exodus from Egypt would be for the modern Jew no more than an antiquarian datum, were it not transfigured by myth into a symbol of his people's continuous experience, an experience of God's continuous design and providence, and an exemplification of all men's continuous progress out of their Egypts, 
forward to their Sinais, and thence, through trial in the wilderness, to the entry of their children into their inheritance.

A legend is a fictional story associated with a historical person or place. Legends often provide examples of the virtues of honoured figures in the history of a group or nation. The story of Jesus of Nazareth became religiously significant the moment it was fused with myths. Then he was "regarded as incarnating and punctualizing an ideal, durative figure, variously represented, in terms of traditional mythology, as the son of God, the son of man, or the Christ, and as symbolizing the constant role of God in man, traduced, yet triumphant" (Gaster 1982:486).

The Christological myth developed after the crucifixion. In order to explain the significance of events like the crucifixion and resurrection, earliest Christianity took up a great variety of designs. This led to pictures of Jesus' supernatural birth, the empty-tomb stories, and the idea of descent into Hades (cf Dinkler 1982:489). Non-historical features were added to his life to emphasize the meaning that his life has had for his community. His story thus became the foundational myth for the cult that arose.

Folktales, a third variety of traditional tale, are usually simple narratives of adventure built around elements of character and plot, for example the Greek tale of Perseus. He saves the Ethiopian princess Andromeda from a sea monster and then marries her (see Van Aarde 2000:184). Folktales may contain a moral or observation about life, but their chief purpose is entertainment.

Myths may include features of sagas, legends, and folktales. What makes one of these tales a myth is its serious purpose and its importance to the culture. Myth presents its images and its imaginary actors, not with the playfulness of fantasy, but with a compelling authority (Frankfort 1946:7). Myths, according to Armstrong (1999:11) were not intended to be taken literally but were metaphorical attempts to describe a reality that was too complex and elusive to express in any other way. Many myths take place at a time before the world, as human beings know it, came into being. Because mythmaking often involves gods, other supernatural beings, and processes beyond human understanding, it is sometimes viewed as a dimension of religion (Brongers 1982:198).

\subsection{Types of myths}

No system of classification encompasses every type of myth, but in discussing myths, it is helpful to group them into broad categories. There are four unanimously accepted categories: cosmic myths, myths of gods, hero myths, and foundational myths. 


\subsubsection{Cosmic myths}

Cosmic myths are concerned with the world and how it is ordered. They seek to explain the origin of the world, universal catastrophes such as fire or flood, and the afterlife. Nearly all mythologies have stories about creation, a type of story technically known as cosmogony, meaning "birth of the world." Creation stories also include accounts of how human beings first came into existence and how death and suffering entered human experience. They work with a tripartite world consisting of heaven above, hell beneath, and earth between (cf Dinkler 1982:487). The Greeks called this arrangement of heaven, earth, and underworld a cosmos, a world order ruled by unalterable law (Harris \& Platzner 1995:46). Cosmogonic descriptions occupy a central position in many mythological accounts. In many religions, they provide, according to Honko (1984:50) a special authority for stories of how a culture originated.

The fundamental difference between the attitudes of modern and ancient man as regards the cosmos and the surrounding world is according to Frankfort (1946:4): "For modern, scientific man the phenomenal world is primarily an 'It'; for ancient - and also for primitive - man it is a 'Thou'." This "Thou" is a presence in nature known only as far as it reveals itself. It is experienced emotionally in a dynamic reciprocal relationship (Frankfort 1946:5). All experience of "Thou" is thus highly individual. Early man was thus convinced that the divine was immanent in nature and nature was intimately connected with society (Frankfort 1946:363). The Greeks, for example saw Zeus as the one who gathered storm clouds, detonated thunder, and hurled lightning bolts. His brother Poseidon was the lord of the sea and earthquakes. The Titan Hyperion (or his son Helios) was the sun, Selene the moon, and Eos personified dawn (Harris \& Platzner 1995:31).

The oldest cosmogonies known today are those of Egypt and the ancient Near East. An example is the creation epic of the Babylonians, Enuma Elish, which dates back to at least the 12th century BC. Another example is the ancient Hebrew account of creation by a single, all-powered deity.

A cosmic drama is expected in the book of Revelation. In mythological language, John speaks about the aeons that has already taken place, and about the Antichrist that soon will come. The apocalyptic signs are, according to Dinkler (1982:488) present or just around the corner and the eternal reign is at hand.

\subsubsection{Myths of the gods}

Many myths do not directly concern human beings, but focus rather on the activities of the gods in their own realm (Noth 1966:287). These myths are called a theogony. They are primarily religious works, which concentrate on 
visions of the gods' births, offsprings, and genealogical descendants (Harris \& Platzner 1995:46). In many mythologies, the gods form a divine family, or pantheon. The story of a power struggle within a pantheon is common to a large number of mythologies. A few places in the Old Testament still give us a glimpse of a struggle between Yahweh and the chaos-monster. (Pss 74:13; 89:11; Is 27:1; and 51:9 see Vriezen 1970:329). They also tell the story of man, living between divine and demonic forces, open to and threatened by the world above and beneath (Dinkler 1982:487).

Myths about the gods are as numerous as the cultures that produce them. The story in Isaiah 7:14 about the virgin who shall conceive and bear a child, has for example been linked, with great probability to the fairly widespread ancient myths, familiar from the Iranian lore of the Saoshyant (Saviour) and from Virgil's Fourth Eclogue, of the virgin-born hero, and of the miraculous child who is to usher in the new age (Gaster 1982:483).

Take for example the Greek god Apollo. He was the son of the god Zeus, and Leto, the daughter of a Titan. Apollo bore the epithet "Delian" from Delos, the island of his birth, and the place where the cult of Apollo was (Kerényi 1976:150). He also had the epithet "Pythian", from his killing of the Python, the fabled serpent that guarded a shrine on the slopes of Mount Parnassus (Kerényi 1976:48). The function of the Greek sun god Helios were transferred to Apollo, in his identity as Phoebus, the radiant, or shining, one, an embodiment of intellectual and spiritual enlightenment (Harris \& Platzner 1995:104). In the Homeric legend, Apollo was primarily a god of prophecy, a seer of future events. As communicator of the gods' will to humanity, he establishes his main sanctuary at Delphi. This was also the site of his victory over the Python. It was also the place of the Pythian cult of Apollo (Kerényi 1976:213). He sometimes gave the gift of prophecy to mortals whom he loved, such as the Trojan princess Cassandra.

Apollo was also the god of agriculture and cattle, and of light and truth. He taught humans the art of healing through his son Asclepius. When Asclepius was still in the womb (Kerényi 1976:107), Apollo killed his mother Coronis for having wedded Ischys; and the crow who told the god about the wedding, Apollo cursed it and, changing its colour from white into black. As Coronis was burning in the funeral pyre, Apollo snatched Asclepius from it and brought him to the wise Centaur Chiron, who brought him up. Apollo, who was a primary source of healing, transmitted his powers to his son (Harris \& Platzner 1995:15).

Asclepius, having become a surgeon, and having carried his art to a great pitch, not only prevented some from dying, he even raised up the dead; for he had received from Athena the blood that flowed from the veins of 
Medus (Harris \& Platzner 1995:104). While he used the blood that flowed from the veins on the left side for the bane of humankind, he used the blood that flowed from the right side for salvation, and by that means, he raised the dead. Zeus did not approve of this and fearing that men might acquire the healing art from him and so come to the rescue of each other, smote Asclepius with a thunderbolt. Both Apollo and Asclepius ascended to heaven after their death (Smith 1971:180).

Both Jesus and Apollonius were like Asclepius, primarily famous as miracle workers and healers, but like him acquired divine fathers and birth stories elaborated with motifs from folklore. "Both were represented as teachers of morality who reformed established temple procedures and participated in or themselves instituted mysteries. Jesus rivaled Asclepius in becoming a principle of cosmic order and a solar deity" (Smith 1971:186). Jesus and Asclepius survived death, while Apollonius escaped it by a miracle, and all three were finally taken up to heaven. Closely associated with that of Apollo, the cult of Asclepius, whom tradition granted posthumous immortality, flourished throughout Greece (Harris \& Platzner 1995:15).

\subsubsection{Myths of heroes}

Nearly all cultures have produced myths about heroes. These stories tend to be tinged with mythological coloration, historical persons, and events assimilated to ideal, mythic characters and situations (Gaster 1982:485). Some heroes, such as the Greek Achilles have one mortal and one divine parent. Others are fully human but are blessed with godlike strength or beauty. The birth and infancy of a mythological hero is often exceptional or even miraculous, like Oedipus. Other heroes were immediately able to care for themselves. Most heroes set off on a quest or a journey of some kind. One of the earliest tales of a hero's journey is the Babylonian story known as the Gilgamesh epic. The most famous tale of a hero's return home is probably the ancient Greek story of Odysseus.

According to Tylor (in Segal 1999:14), it would be wiser to classify hero myths as legends rather than as myths. Jung disagrees. For him the hero myths are projections onto mere human beings of a divine or quasi-divine status. With that, he means that the hero myth is an unconscious drama seen only in projection, like the happenings in Plato's parable of the cave where the hero himself appears as a being of more than human stature (Segal 1999:69). Psychologically seen the hero in the myth is the ego consciousness, which in the first half of life must defeat the unconscious out of which it has emerged and which in the second half of life must return to the unconscious and reconcile itself with it (Segal 1999:85). 
One of the best-known heroes in the Greek mythology is Hercules. He was noted for his strength and courage and for his many legendary exploits. Hercules is the Roman name for the Greek hero Heracles. He was the son of the god Zeus and Alcmene, wife of the Theban general Amphitryon. Hera, the jealous wife of Zeus, was determined to kill her unfaithful husband's offspring, and shortly after Hercules' birth, she sent two great serpents to destroy him. Hercules, although still a baby, strangled the snakes (Harris \& Platzner 1995:214). Zeus persuaded his wife, Hera, to deify Hercules by adopting him as her son. She adopted him to protect him against the shame of adultery and to legitimize his deification (Van Aarde 2001:174).

As a young man, Hercules killed a lion with his bare hands. As a trophy of his adventure, he wore the skin of the lion as a cloak and its head as a helmet (Fontenrose 1959:405). Hera was so annoyed at Hercules' growing fame that she cast a spell of madness over him. Out of control, Hercules killed his own wife and children. His remorse was so profound that when he returned to his senses he could find no peace of mind. He visited the oracle of Delphi to see how he could demonstrate his remorse (Fontenrose 1959:401). The oracle advised him to obey the orders of Eurystheus, his cousin, the king of Tiryns and Mycenae. Eurystheus ordered Hercules to accomplish twelve difficult tasks. He completed the twelve labours and is celebrated to this day for his great courage and strength. According to Aune (1990:4), the Old Testament figure of Samson clearly belongs to the Hercules tradition.

Hercules' life was one of self-sacrifice and sadness. He was considered the greatest example of the Cynic lifestyle by Julian (Or. 6.187C). Like Hercules, the Cynic lived simply and endured pain and suffering in order to be liberated from the constraints of physical life. Cynics proclaimed this message of liberation to all who would listen (Aune 1990:8). Hercules was of the Age of Heroes, the fourth generation of mortal men on the earth. Half-man half-god, he was the focus of considerable wrath and love from the immortals. A being divided against himself, Hercules "embodies the quintessential heroic predicament: how to fulfil the demands of the godlike desires for knowledge and achievement that drive him while bound to a mortal body that can neither fly nor turn invisible and which will surely die" (Harris \& Platzner 1995:213). Without the comfort of a wife or children, he spent most of his life as a wanderer, ventured out into the world, not necessarily seeking adventure but, more likely, to live a life that was not dominated by vengeful immortals or vindictive relatives. Hercules was the archetype for bravery and living proof that might-makes-right. He was more than a match for men and gods a like.

In all his quests, Hercules "calls upon his divine gifts to commit deathdefying acts, but, tainted by his human inheritance, he must finally confront 
the most formidable obstacle of all: his own death" (Harris \& Platzner 1995:220). Twice, Hercules voyages to the Underworld, undertaking the archetypal rite of passage that all heroes must fulfil in this most urgent of human quests (Fontenrose 1959:327).

\begin{abstract}
Having thus gone to the Land of the Dead and been reborn twice having taken on Death himself, and won - Heracles transcends the limits of the human condition, achieving literally what most heroes can achieve only through the consolation of an immortal reputation. Heracles, like most hero figures, thus mediates the most extreme of contradictions - not only those of nature and culture, but those of life and death.
\end{abstract}

(Harris \& Platzner 1995:220)

Hercules was said to have no grave. According to some versions of the myth, his soul goes to the Underworld, while only his reputation endures: other versions, however, portray Hercules as raised up by the gods from his funeral pyre to be a god on Olympus, where he is reconciled to Hera and married to her daughter Hebe, fulfilling at last the quest for immortality, that is central to the heroic endeavour. Homer, combining both versions in the Odyssey (book 11), describes Hercules' human part remaining as a shade in Hades, while his divine self takes up residence with the gods. The hero thus, remains divided in death, as he was in life, as complex as human nature itself (Harris \& Platzner 1995:220). He was worshipped by the Greeks as both a god and as a mortal hero.

Quite a few attempts were undertaken in the past to call attention to the similarities and parallels between aspects of the life of Jesus and the life of Hercules. There were Emil Ackermann, Theodor Birt and Friederich Pfister. Pfister listed according to Aune (1990:11) twenty-one parallels. Then there was Arnold Toynbee who found twenty-four points of correspondence between the Jesus of the gospel and the Hercules of Greek legend. These findings suggest that the legend of Hercules may be an important common source from which the story of Jesus on the one hand and the stories of the pagan historical heroes on the other may have derived some of their common features (Aune 1990:13). Aune (1990:14) suggested several Christological traditions in The Letter to the Hebrews that exhibit themes and motifs that are associated with ancient conceptions of Hercules.

One of these conceptions is the title son of God. Both Jesus and Hercules are called the son of God. Both filled the role of a high priest who through prayer was as a helper and giver of strength and grace to people in 
the difficulties of life. Both were obedient to God/Zeus, and although the notion of resurrection is largely absent from Hercules' legends, the notion that he was raised to Olympus with divine status was an integral part of the Hercules myth (Aune 1990:19). For both, death and ascension to heaven resulted in deification.

Another hero as a holy man to take briefly note of is Apollonius of Tyana. He was known for doing miracles of healing. The similarities between the Gospels and Acts, and the stories of wandering holy men were pointed out by many scholars in the past (Smith 1971:177). Bieler (in Koskenniemi 1998:461) outlined the conventional features in the life of a divine man as follows: "the birth of a divine man is prophesied, and at the moment of his birth miracles occur. From his very youth he is an authoritative teacher, attracting crowds of people and performing great miracles. He is regarded as the son of a god. Thus, people show a divine respect for him. On the other hand, he has enemies. He is accused of sorcery and is put to death. After his miraculous death, he rises again and appears to his own followers." Apollonius lived in the late second century. Our main source is a work of Philostratus dating from ca 220 CE. His life and the life of Jesus demonstrated all these features.

Then there was Perseus. As mythological hero, he was a fatherless son who became a hero (Van Aarde 2000:181). According to the myth, Perseus was the abandoned son of Danae by Zeus. Danae was the daughter of King Acrisius of Argos. The king was warned by prophecy that his daughter's son would kill him so he shut her away in a tower. Zeus went through a narrow window to her in the form of a shower of gold and she became pregnant. Danae called her son Perseus (Van Aarde 2000:182). Perseus was thus a son of god, the god Zeus, born from a virginal conception. He became a hero for rescuing Andromeda and for killing Acrisius with a discus at the games.

Other well-known heroes are the (mythic) figures we know from the Old Testament. Moses, Joshua, Elijah, and Elisha were all known as miracle workers. The miracles of Jesus are very similar to theirs, especially to the miracles of Elijah and Elisha. Jesus feeds people in a miraculous way (cf $1 \mathrm{Ki}$ 17; 2 Ki 4), heals leprosy (cf 2 Ki 5), raises from the dead (cf $1 \mathrm{Ki} \mathrm{17),} \mathrm{walks}$ on water (cf $2 \mathrm{~K} 2$ ). Elijah was understood as a prophet like Moses (Dt 18:18), and the miracles of Elisha serve to legitimize his role as successor of Elijah (Koskenniemi 1998:465). Many of these hero stories from the Jewish tradition were reinterpreted and used as part of the Jesus myth. Miracle stories were used to legitimize leadership in the Temple in the last days of Jerusalem and in Cyrene during the aftermath of the war (Koskenniemi 1998:466). 


\section{FOUNDATIONAL MYTHS}

For almost all the holy places and feasts, there are etiological narratives that explain why these places, persons, or feasts are important for a certain community. Myth tells that kind of story, which purports to tell of the occasion on which some religious institution, a cult or certain of its rites and festivals, had its beginning, and of the divine acts which set the precedent for the traditional acts performed in the cult (Fontenrose 1959:4).

Christianity is no exception. The narrative of Jesus of Nazareth may be regarded as the precipitating or generative event for Christianity. According to McGrath (1990:35) a "community and an associated foundational narrative arose in direct response to that history, which sought to identify and legitimate both the existence of that community as a social entity and its distinctive understanding of God and human nature and destiny with reference to the perceived significance of Jesus of Nazareth."

There is also nothing unique to the foundational myth of Christianity because myths of virginal conceptions, ascensions to heaven and being adopted by the gods are recycled language. In this regard, according to Van Aarde (2000:184), Seneca's tragedies of Hercules' adoption and Ovid's story of Perseus' conception are most striking. Perseus as a fatherless son also became a hero, and the ancient Eastern myth of Osiris, together with other eastern Hellenistic myths, recounted how the sons-of-gods suffered the human fate of death but again rose from the death (see Van Aarde 2000:186).

The narrative of Jesus of Nazareth, together with the Easter kerygma, served as the foundational myth for early Christianity. The character of the Christian community arises thus from their willingness to let this narrative govern their communities' understanding of its historical ${ }^{4}$ situation and future. According to McGrath (1990:54) the narrative of Jesus of Nazareth shaped their views and attitudes to power, to pride, to loss, to death, to grief, and to despair. According to McGrath (1990:54), Jesus assumes a role within the community of faith equivalent to that assumed by Florence for Dante or Giotto. It thus evokes a deep sense of happening, and it keeps the memory of a foundational narrative and its present significance for the community whose identity is inextricably bound up with it. It thus provides a focus of identity for the community.

The New Testament, as the collection of these myths, provides a significant theological foundation for the correlation of the narratives. The New Testament writings affirm, according to McGrath (1990:54) the conformity of the member of the community to Christ, namely that through faith, those who

\footnotetext{
${ }^{4}$ In a first century perspective of history.
} 
believe in Christ are somehow caught up in him, so that his history becomes their history, his death is their death, and his life is their life.

The vision of the community is thus shaped and informed by the foundational myth, namely the story of Jesus of Nazareth, recalled in the eucharistic celebration of his death and resurrection and the benefits, which these are understood to bring them.

\section{INTERPRETING MYTHS AND RITUALS}

\subsection{An overview on the interpretation of myth}

The universal human practice of mythmaking appears to be the earliest means by which people interpreted the natural world and the society in which they lived. Thus, myth has been the dominant mode of human reflection for the greatest part of human history. A person viewed happenings in his world as individual events. An account of such events, and their explanation can be conceived only as action and necessarily take the form of a story. In other words, according to Frankfort (1946:6), the ancients told myths instead of presenting an analysis or conclusions.

Many ancient writers portray historical events in language reminiscent of traditional myths (Gaster 1982:485). Greek thinkers of the 6th century BC were the first people known to question the validity of mythmaking. The meaning of a myth must thus be rediscovered by interpretation. Dinkler (1982:489) said: "The leading question in dealing with myth must be: What is principally said about man's existence before God, of man's selfunderstanding in the midst of this world and history?" In the early stages of Greek civilization, as in other ancient cultures, the truth of myths was taken for granted (Dinkler 1982:487). The Greek word mythos, from which the English word "myth" is derived, was originally used to describe any narrative. Early Greek authors who employed the term drew no rigid distinction between tales that were historical or factual and those that were not.

In the 6th century, however, Greek thinkers began to question the validity of their culture's traditional tales, and the word mythos came to denote an implausible story. Greek philosopher Xenophanes, for example, argued that much of the behaviour that the poets Homer and Hesiod attributed to the gods was unworthy of divine beings. He said: "Man made his gods and furnished them with his own body, voice and garment" (Corsar et al 1977:7). By the 5th century $\mathrm{BCE}$, serious Greek thinkers tended to regard the old myths as naive explanations for natural phenomena or simply to reject them altogether. Nevertheless, myths retained their cultural importance, even after 
they had come under attack from philosophers. The ancient Greek tragedies, which remained central to civic and religious life in Athens through the end of the 5th century BC, drew their subject matter largely from myths.

In the early 4th century BCE, Greek philosopher Plato systematically contrasted logos, or rational argument, with mythos - which in Plato's view was little better than outright falsehood. In his philosophical dialogue "The Republic" Plato argued that the ideal commonwealth should exclude traditional mythological poetry because it was full of dangerous falsehoods. Plato himself nevertheless devised myths of a sort to explore such topics as the birth of the world and death and the afterlife, which in his view fell outside the boundaries of logical explanation. Plato distinguished between myth and allegory. A myth was according to him (Bidney 1953:304) a traditional narrative about gods or some culture hero, and an allegory, by contrast, was a fictional narrative with symbolic meaning. An allegory was deliberately invented for its symbolic truth and it was not intended to be taken literally.

After Plato, most thinkers either tried to apply reason to the supernatural elements in myths or interpreted them symbolically. The Stoics and, much later, the Neo-Platonists interpreted myths as allegories. That is narratives, which employ picturesque language and images to convey a hidden message. They reinterpret the myths so, as to read into them their own philosophy of nature (Bidney 1953:305).

During the 17th and 18th centuries, the so-called Age of Enlightenment, the allegorical interpretation of myths fell into disfavour. At the beginning of this period, myths were dismissed by intellectuals as absurd and superstitious fabrications, in part because of a climate of hostility toward all forms of religion (Klapwijk 1977:115). But, in the late 17th century, a different approach to mythology arose in the context of new information about mythmaking peoples.

Europeans had become aware of these peoples in the course of the voyages of discovery of the 16th and 17th centuries. Working on the assumption that these cultures could provide insight into the experience of prehistoric societies, European scholars sought the origins of mythology in the "childhood of man," when human beings supposedly first formulated myths as a response to their physical and social environment (Klapwijk 1977:116).

Most analyses of myths in the 18th and 19th centuries showed a tendency to reduce myths to some essential core. This core remained once the fanciful elements of the narratives had been stripped away. One of the many paradoxes of the study of myth is the fact that interest in it peaks in the 20th century, the age of great technological discoveries and a desperate human search for meaning. 
In the 20th century, investigators began to pay closer attention to the content of the narratives themselves. E B Tylor, for instance read myth literally. He considered myths to be expression of a kind of primitive mentality that is incompatible with the modern odes of progress and reason (Boskovic 2001b:1). Myth is thus totally opposed to and incompatible with science. Therefore, myth is for him a passing phenomenon. He argued that humans have myths only until they discover science (Segal 1999:10). He was convinced that there is no myth outside religion. Religion is also a form of primitive science. Myth explains the hierarchy of the gods, their biographies, their past behaviour, and their relationship to humans. Thus, myth completes the explanation of the world provided by the rest of religion (Segal 1999:13). It is called: myths of origin ${ }^{5}$.

Mythology has often been an attempt to explain the inner world of the psyche (Armstrong 1999:245). Austrian psychoanalyst Sigmund Freud held that myths, like dreams, condense the material of experience and represent it in symbols (Van Niekerk 1996:64). As Freud saw it, myths express suppressed sentiments and desires in the unconscious, the Id. His grand vision was to emancipate his patients and indeed all of mankind, from the thralldom of Id and usher in the age of rationality. The myths must be interpreted, their true meaning deciphered, and mythological imagery replaced by rational language (Bidney 1953:318).

Freud used his knowledge of Greek and Jewish mythology to analyze his patients' dreams (Meyer, Moore \& Viljoen 1988:61). Freud argues that dreams "which typically resemble myths in their imagery and narrative form, are fundamentally the fulfilment of wishes that the waking mind suppresses or denies. Freed of mundane restraints, the dreamer can fly like Icarus, descend into Hades like Orpheus searching for his Eurydice, or battle fire-breathing dragons like Perseus and Apollo" (in Harris \& Platzner 1995:34). Dreams, like myths thus, permit one to violate taboos and it gives the dreamer an emotion and activity very different from that of the dreamer's daylight experience. Freud's most celebrated example of mythic wish fulfilment that violates societal taboos is from the story of Oedipus, the king of Thebes.

... kills his father and marries his mother. According to Freud's theory of infantile sexuality, the male child passionately desires exclusive possession of his mother, whom he regards as the source of all nurturing pleasure. To claim the mother entirely, he must eliminate his male parent, whom he instinctively recognizes as the chief rival for his mother's affection. Upon growing older and discovering that both his incestuous feelings and hostility towards

\footnotetext{
${ }^{5}$ Foundational myths.
} 
his father are unacceptable, the boy experiences guilt and gradually banishes such forbidden wishes from his conscious mind.

(Harris \& Platzner 1995:35)

This guilt-ritual is best expressed for Freud in the figure of Christ, and in the account of his life, death and resurrection. Among all the son religions, Christianity occupies a special place because Christ is the son who sacrifices his own life to redeem the company of brothers from original sin. According to Freud (Megal 1979:203), two features of ambivalence come together in this sacrifice. On the one hand, the guilt from the killing of the father is avowed and expiated; but at the same time, the son himself becomes the god, replacing the father religion by the son religion. A clear expression of this ambivalence is for Freud the revival of the totem meal in the eucharist. Its meaning is both the reconciliation with the father and the substitute of the son for the father, with the faithful consuming the son's flesh and blood (Megal 1979:203).

Carl Jung took Freud's psychological approach in a different direction. Jung viewed myths not as relics of the infancy of the human race, but as revelations of humanity's tendency to draw on a collective universal store of what he called archetypes (Van Niekerk 1996:88; cf Tigue 1994:21). The subject matter is according to Jung not literal but symbolic: not the external world but the human mind. The human mind tends to express symbolically that which is poorly understood intellectually (Van Aarde 2000:180). Myth thus originates and functions to satisfy the psychological need for contact with the unconscious (Segal 1998:3).

\begin{abstract}
After studying thousands of myths from cultures all over the globe, Jung was struck by their similarity to dreams in which the same major figures kept reappearing. It did not matter whether the myth or dreamer - was Italian, Japanese, African, American, or Indonesian; figures of the great mother, stern paternal judge, threatening stranger, clever trickster, or benign guide were consistently present.
\end{abstract}

(Harris \& Platzner 1995:36)

Jung found that not only the basic human emotions such as fear, desire, and greed dominate both dreams and myths, but also particular situations and actions - journeys, encounters with frightening monsters, struggles with 
unidentified assailants, all of these phenomena were universal (Harris \& Platzner 1995:37).

Myths thus function to reveal the existence of the unconscious and to open up to it (Segal 1999:24). According to Jung, myths can be used to establish the collective unconscious. Myth is also the best medium for conveying the unconscious. According to Jung (Segal 1999:75), every society as well as every individual inherits myths. That is an inborn disposition to produce parallel thought-formations. The myth of Odysseus for example, "is passed on from generation to generation by acculturation, but the hero archetype that it expresses is passed on by heredity" (Segal 1998:17). There are, however, a limited number of archetypal motifs, or primordial images, which appear in myths and dreams (Bidney 1953:321).

Myths can also be described as identical psychic structures common to all men. Jung called it archetypes of the collective unconscious. "For Jung, these archetypes spring from the collective unconscious of the entire human race, inspiring dreams, religious visions, and mythologies" (Harris \& Platzner 1995:37). These archetypes are like templates for organizing the universal themes that recur in human experience. In different cultures and at different times an archetypal content will be symbolically expressed in somewhat different ways, but it will still reflect the basic human experience underlying it (Van Aarde 2000:180). Living in the twenty first century, we can thus still relate to myths of birth, testing, conflict, death, and rebirth that originated thousands of years ago because we have inherited these mythic archetypes from our remotest ancestors. One is thus born with myths.

According to Jung, myths must, to reach their intended audience, be translatable into a language the audience knows. Just as archetypes must be translated into myths, so myths must be translated into the language of those whose myths they are. Just as archetypes are dependent on myths to convey their meaning, so myths are dependent on interpretations to convey their meaning (Segal 1998:11).

The prime function of myth is thus psychological, namely to reveal the unconscious and to help one to experience it, therefore Jung (1984:248) said that the "primitive mentality does not invent myths, it experiences them." This experience of myth, according to Jung provides the best entrée to the experience of God (Segal 1999:91; cf Tigue 1994:3). Another function is the existential function of myth. Myths makes humans feel at home in the world, even if it does so by explaining events in the world (Segal 1998:19).

For Jung the life of Christ is Christian mythology. The statement that he rose from the dead is to be understood not literally but symbolically (Segal 
1999:91). Christ's life is a symbol of the archetypal journey of the hero from primordial unconsciousness (birth) to ego consciousness (adulthood) to return the unconscious (crucifixion) to re-emergence from it to form the self (resurrection). The figure of Christ thus manifests many dimensions of the archetype of the self (Megal 1979:211). Christ is the light of the world, the fullness of humanity, the spotless lamb, the perfection of manhood, and the hero of the struggle with death and evil. Another important mythological symbol for Jung is the archetypal child (Jung 1984:251). According to Jung, one of the essential features of the child motif is its futurity. The child is potential future. Therefore, it is not surprising that so many of the mythological saviours are child gods. This agrees according to Jung exactly with our experience of the psychology of the individual, which shows that the "child" paves the way for a future change of personality (Segal 1998:27).

Jung does not have the same neurotic preoccupation with guilt and futile atonement as Freud, when he evaluates the Christ myth. The figure of Christ symbolizes for Jung (Megal 1979:211) elements of psychological maturity, psychic integration and wholeness. Jesus of Nazareth could never have made the impression he did on his followers, if he had not expressed something, that was alive and at work in their unconscious, and Christianity could never have spread through the pagan world with such astonishing rapidity, according to Jung, had its ideas not found an analogous psychic readiness to receive them (Megal 1979:211). The Christian gospel contains according to Eliade (see Megal 1979:217) many if not all of the archetypal motifs that are to be found in the myths of primitive religions.

Myth and religion have according to Jung, traditionally worked in tandem. "Religion has preserved myth, and myth has sustained religion. The heart of religion for Jung is neither belief nor practice but experience, and myth provides the best entrée to the experience of God, which means to the unconscious" (Segal 1998:35). Jung praises early Christianity for both adopting and adapting various pre-Christian myths. It proves the myth's vitality but it also proves the vitality of Christianity, which was able to interpret and assimilate so many myths. A religion that fails to interpret its myths is dead. The spiritual vitality of a religion depends on the continuity of myth, and this can be preserved only if each age translates the myth into its own language and makes it an essential content of its view of the world (Segal 1998:35). The theory of Jung makes sense to me, and it underlines my own experience and understanding.

Modern Christianity, according to Jung (see Segal 1998:37), has failed to update its myths. It has also erred in its attempt to update itself by eliminating myth. Myth is indispensable to experience and thereby to religion. By eliminating myth, it has eliminated experience as well (Segal 1998:37). 
Myth must not be eliminated, it must be reinterpreted. To make it acceptable for moderns, it must be interpreted symbolically.

Mircea Eliade regarded myths primarily as sacred stories related to the events that occurred in illo tempore, in the mythical time following the creation of the world, and long before the advent of history (Eliade 1961:57). This mythical time, illud tempus is separated by an immeasurable gap from our time, and the only way to approach it is through myths (Boskovic 2001a:7). Eliade (1961:161) claimed that the symbol, the myth and the image are of the very substance of the spiritual life. According to him, myths thus give sacredness, or religious meaning to physical objects and human acts (Van Aarde 2000:180).

While the Christ myth might manifest universal truths, every myth and every symbol are conditioned by the particulars of the time and place within which it is participated in by the faithful. Thus, when the son of God incarnated, according to Eliade (in Megal 1979:222) and became Christ, he had to speak Aramian. He could only conduct himself as an Aramaic of his time, and not as a yogi, a Taoist or a shaman. His religious message was conditioned by the past and present of the Hebrew people. If Jesus had been born in India, the decor of the myth would have been different. Thus, the message of the myth is bound by the limitations of the cultural climate of its day.

According to Joseph Campbell (1972:13), who strongly supports Jung's view, myths are telling us in picture language of powers of the psyche to be recognized and integrated in our lives, powers that have been common to the human spirit forever, and which represent that wisdom of the species by which man has weathered the millenniums. Campbell thus sees myth as an eternal possession that can never be displaced by the findings of science. The problem with the romanticists is that they put myth at the top of the cultural disciplines as an independent source of artistic truth-values, as well as a key to the understanding of a people's culture (Bidney 1953:307).

According to Campbell (1972:13), mythology has four functions. The first one is installation of a sense of awe before the "mystery of existence," a feeling that incorporates the recognition of the numinous, which is characteristic of all religions. The second basic function is the establishment of a cosmology, or image of the universe. The third is support for the existing social order, since myths are always essentially conservative. Finally, the fourth basic function is introducing the individual to the order of reality of his own psyche, leading this individual towards his or her spiritual self-realization (Boskovic 2001a:7).

Segal (1999:139) objects to Campbell's universalistic and psychological-symbolical interpretation of myths. This problem could be avoided if the psychological interpretation of myths would regard the theories 
of historians and anthropologists with more respect and would examine the meaning of myths more relative to the given time and community from which they emanated.

French anthropologist Claude Lévi-Strauss (see Segal 1999:46) argued that the primary function of myth is to resolve contradictions between such basic sets of opposites as life and death, nature and culture, and self and society. Myth is distinctive in not only expressing oppositions, which are equivalent to contradictions, but also resolving them, thus the purpose of myth is to provide a logical model capable of overcoming a contradiction (Segal 1999:46). Myth as the resolution of these contradictions is a primitive possession. He also argued that myth as primitive science has been succeeded by modern science (Segal 1999:2). Myth is thus, according to Susanne Langer (in Bidney 1953:287) part of an evolutionary process of development. Because myths are elements of culture, Bidney (1953:323) said, it must be investigated with the same empirical and critical methods employed in the study of culture in general.

Apart from the psychological and anthropological views on myths, there are also philosophical attempts to interpret myth. This attempt reaches its most elaborate level with the works of Ernst Cassirer. Cassirer (in Schultz 2000:14) sees myth as one of the stages in the process of "humanization". It is a necessary step in making humans what they are today. According to him, myths are on a lower level than philosophy or science, but the stage of "mythic thinking" has in itself the kernels of the stages that are yet to come. Although lower and primitive, it is a necessary stage in human development, and any higher stage is simply unthinkable without it. Cassirer defines six major cultural activities of man namely art, science, language, history, myth and religion (Schultz 2000:13).

According to Cassirer, then, man has discovered a new method of adapting himself to his environment. Between the receptor system and the effector system, which are to be found in all animals, we find in man a third link which may be described as the symbolic system. This is a new dimension of reality and in this dimension, mythic thinking was born. Man cannot escape from his own achievements. He thus now lives in a symbolic universe where language, myth, art, and religion are parts of (Bidney 1953:315). Man has so enveloped himself in linguistic forms, in artistic images, in mythical symbols or religious rites that he cannot see or know anything except by the interposition of this artificial medium. Myth is thus shown as inner logic or form for Cassirer (in Schultz 2000:38). All the ideas of mythical societies exhibit a pattern of relating to each other.

Many symbols have no referents or corresponding things in reality. These can be regarded as mythological symbols. According to Mann (2002:2), regarding these mythological symbols as part of physical reality is "primeval 
stupidity". Primeval stupidity is the inability to make a clear and sharp distinction between the symbol (in our symbolic reality) and the thing (in physical reality) it represents.

Cassirer's first critical study of myth was published in 1922. The anthropological data that he had access to were not always assembled in a critical manner, nevertheless, the fact remains that Cassirer clearly recognized the importance of myth, as well as the connection between language and myth and the importance of language in human understanding. Cassirer sees myths as early patterns of thought. Thus, man perceives the world in symbolic forms, and science is only one of many other forms (Bidney 1953:315).

Myths are products of some sort of a disease of the language, originating from the human incapacity to express their emotions in relation to nature within the limits of language they use. Thus, man has to use metaphor as the only way to reconcile his emotions with their expression and representation (Boskovic 2001a:6). Metaphor can therefore not be overlooked when one speaks of myth. Metaphor is clearly one of the foundations of all our mental activity, a foundation upon which our systematic logics of rational inquiry also rest, or to use a better metaphor, it is a ground out of which they grow. Myth and our everyday language are permeated with metaphor. Cassirer remarked that the same form of mental conception is operative in both myth and language (Schultz 2000:43). For Cassirer metaphor is the single door that opens onto everything and nothing. Its function relies on the past's essential equivocation between what is and what is not. While concepts give form, and perceptual activity sense, metaphor is the wellspring of meaning. Cassirer (1955:62) suggested that we should interpret myth in a tautegorical $^{6}$ and not in an allegorical way (cf Van Aarde 2003b:17). "An allegorical interpretation of myth would apply standards of truth or meaning not part of the worldview [in which the myth as speech act is embedded]. A tautological interpretation defines meaning and judges its truth according to standards that are part of the worldview" (Schultz 2000:162).

With Claude Lévi-Strauss' article The Structural Study of Myth in 1955, he announced the coming of structuralism to the anthropological study of

\footnotetext{
${ }^{6}$ The term "tautegorical" is derived from the Greek words tauta and goreó and "allegorical" from the words allos and goreó. Etymologically, "tautegorical" would mean, "to convey the same things" and hermeneutically, it refers to an understanding of the meaning of language as a symbol of communication within the framework of the worldview from which it emanated and for which it is meant. "Allegorical" means, "to convey differently" and denotes the interpretation of language as symbol of communication within another worldview. The dialectical-hermeneutical approach attempts to "interpret" the earlier communication of an ancient worldview in a non-allegorical and non-positivistic manner, in order for it to communicate existentially in a later context. In this sense, allegorical interpretation pertains to positivism and tautegorical interpretation to abductive reasoning which has replaced deductive and inductive epistemology (see Van Aarde 2003b).
} 
myth. Myths for him, offer direct insight into the ways the human mind operates. He considered the processes of how the human mind functions to be universal (Boskovic 2001b:12). Ricoeur criticized structural analysis for "de-chronologizing" the narrative, since the structural analysis tends to reduce the role of plot to a secondary function of figuration in relation to underlying logical structures and the transformation of these structures (Boskovic 2001b:13). Nevertheless, the structuralist insistence on language, as well as on the use of signs and symbols in the explanation of myths, was an important step forward.

Levi-Strauss (see Boskovic 2001b:13) observed that metaphor is not a later embellishment of language but it is one of its fundamental modes - a primary form of discursive thought. Myth is thus, according to Niditch (1996:19) a product of the human mind working in its poetic, metaphoric mode.

Most simply, metaphor involves representation of one thing as though it were something other. According to Ricoeur, it is a "deviant naming" that generates a new light on the thing being represented. Ricoeur's extensive writings on metaphor can be interpreted as an elaboration on Merleau-Ponty's view of language and creativity (Gay 1992:3). Rejecting any exact knowledge of or adequate language for "things in themselves" or "reality," Ricoeur, according to Gay (1992:3), still views metaphor as one of our best vehicles for enriching our expression and perception. Although he focuses on how metaphor re-describes reality, he stresses that its role is more hermeneutic than ontological, that means metaphor interprets, not makes, reality. The creative function of metaphor pertains to its impact on changing our perception. As Ricoeur says (in Gay 1992:3), the purpose of metaphor is neither to improve communication nor to insure univocal argumentation, but to shatter and to increase our sense of reality by shattering and increasing our language.

For Ricoeur (in Gay 1992:3), both metaphor and ideology ensure polysemy, although he makes these points separately and does not pursue their joint effect for his theory of creativity. He presents metaphorical exploitation of polysemy as the heart of linguistic creativity. Ricoeur's view seems to deny that a non-ideological discourse is possible (Gay 1992:3).

Metaphor thus sets thinking in motion, but in non-factual ways. Metaphors do not work simply by reflecting commonly recognized similarities between things; rather it would be more illuminating to say that metaphor creates the similarity than to say it formulates some similarity antecedently existing. What metaphor most clearly exemplifies is the creative power that 
human beings inherit with orality. We do not all use it equally, but we all have access to it.

\subsection{Interpreting rituals}

Another important issue to keep in mind is that myths and rituals operate together. Rituals, according to Theissen (1999:2), are patterns of behaviour, which repeat themselves, patterns with which people break up their everyday actions in order to depict the other reality that is indicated in myths. Myths are the traditional stories that accompany rituals (Fontenrose 1959:3). According to Honko (1984:51), the context of the myth is the ritual. Ritual gives form to human live, not in the way of a mere surface arrangement, but in depth (Campbell 1972:43). Rituals take people out of the old structures of society into a "new" society (see Turner 1969:15). Ritual is a religious or quasireligious "ceremony in which a prescribed series of actions - accompanied by the repetition of traditional phrases - are scrupulously observed" (Harris \& Platzner 1995:32). According to James George Frazer, myths describe the character and behaviour of gods, where rituals seek to win divine favour (Segal 1999:39). William Robertson Smith's emphasis on the social components of religion in his book Kinship and Marriage in Early Arabia, led him to postulate that it is the action that matters, much more than the belief. The ritual, therefore, must come before the myth (Boskovic 2001b:4). Smith believed that ritual should be considered before myth in not only order of importance, but also that ritual literally preceded myth in time. Actions come first, human attempts to explain and rationalize them afterwards.

The two basic functions of rite, according to Theissen (1999:122-123) are in the first place to structure time, and secondly to co-ordinate people. The structuring of time can be seen in early Christian baptism as initiation rite. Theissen (1999:123) indicates that the co-ordination of life in communities mainly took place through sacrifices, especially where it were connected with shared meals. The early Christian eucharist is thus a rite of integration, which is constantly repeated and renews the cohesion of the community.

This concept of the subordination of myth to ritual did not last very long. One must rather speak of an interdependence of myth with ritual (Boskovic 2001b:10). For the anthropologist Clyde Kluckhohn (see Segal 1999:45) myth provides prescribed ways of understanding and ritual prescribed ways of behaving. The myth thus explains what the ritual enacts. In a sense then myths are the by-product of rituals. Kluckhohn remained close to the psychology-influenced theories, since he concludes that myths and rituals equally facilitate the adjustment of the individual to his society. They have a common psychological basis, and in a sense they are supra individual. They 
are both cultural products, part of the social heredity of a society (Boskovic 2001b:10).

For Cassirer, we must, in order to understand myth, begin with a study of ritual. Ritual is, according to him (Bidney 1953:316) a more fundamental element in man's religious life than myth. Myth is the epic element and rite is the dramatic element in primitive religious life. Myth serves to rationalize and symbolize rite. To Cassirer then, myth is nothing but the interpretations of rites. With this view, he connects to a larger extent to Smith than to Kluckhohn.

Thus, it seems that myths are stories invented to explain ceremonies, whose real origins have long been forgotten (Harris \& Platzner 1995:32). Rituals therefore comprise, according to Theissen (1999:3) of words of interpretation, actions, and objects. In the words of interpretation, the myth is made present in concentrated form. Through them actions take on symbolic surplus value and as signs are related to the other reality. Then, based on this surplus value the objects present in the rite are removed from everyday, secular use and it becomes a religious expression.

Edmund Leach can go along with this when he says that ritual is a symbolic statement, which says something about the individuals involved in the action. Myth is for him too the counterpart of ritual (see Boskovic 2001b:11). Myth implies ritual and ritual implies myth, thus they are one and the same. For Leach (see Boskovic 2001b:11), myths are only one way of describing certain types of human behaviour, and ritual action and belief are alike to be understood as forms of symbolic statement about the social order. Or, as Honko (1984:51) said: "Myth provides the ideological content for a sacred form of behaviour. Ritual brings the creative events of the beginning of time to life and enables them to be repeated here and now, in the present." This is also Gaster's (1984:113) viewpoint. According to Gaster, the purpose of ritual is to present a situation in which present and actual individuals are involved. However, according to Lévi-Strauss myths and rituals, although linked, remain opposing rather than parallel members of a pair (Segal 1999:46).

There are still scholars who would like to think that Jesus, in anticipation, to his forthcoming passion, instituted the "last supper" as a Christian ritual. However, one must be careful not to interpret the ritualization of the meal in terms of later Christian eucharist theology. According to Mack (1995:120), the Corinthian Christians certainly did not. The story of the eucharist is an etiological legend. Paul referred to it as if it were the historicized form of the community's foundational martyr-meal myth. The text is thus evidence for the ritualization of the common meal, using its two special 
moments to recall the founder's death. If one assumes (see Mack 1995:118) that the meal was ritualized in the process of working out the Christ myth, one can identify the symbols with two figures. One is "my body for you"; the other is "the new covenant in my blood." Both of these figures belong to the myth of the martyr. Body and blood as symbols make sense within the tradition of martyrological thought. The identification of the meal symbol with the mythic reference to martyrology was made by means of the formula "this is." The eucharist is thus the ritual that accompanies the Christ myth.

The kerygma of the earliest followers of Jesus states that his martyrdom was a sacrifice, which replaced the many sacrifices. The kerygma was about death and resurrection. The kerygma asked for narratives. The narratives were used in the cult as material for sermons. These narratives which ended with a belief in the resurrection of Christ, became the foundational myth for the Christ cult, for its preaching and, at a secondary stage in the development of the cult, it was connected with a ritual. Then, according to Theissen (1999:125), a symbolic action with an eschatological orientation came into being, and an ordinary meal became a forerunner of the eschatological meal, in memory of the death of Jesus.

\section{CONCLUSION}

The books of the Bible are antique documents from a world that has gone by. This world functioned within a mythological paradigm. They used myth to express their experience of the transcendent. They used myth to make sense out of their reason for existence. Their myths were not unique. They used and recycled older and already existing myths known to the world were they lived. Myth was the vehicle they used to communicate faith. Therefore I do not evaluate myth negative. I evaluate a positivistic interpretation of myth negative. One does not need a mythological worldview to use, understand, and to appreciate myths. One can appreciate the value of myths even in a postmodern world.

Myth is just as important to postmodern humans, as it was to our premodern ancestors. The Christ myth is a first century Mediterranean version of the ancient inherited subconscious archetypal myths of humankind. It is stories in the language, symbols, and metaphors of the cultures and peoples in which it originated. It is language recycled.

To read the myth literally is an error. It was not even valid to read it literally in the first century. Because one cannot read it literally, the reading of the myth leads to metaphorical interpretation. Psychologically speaking, when reading the narrative, one's subconscious connects with the truth hidden 


\section{At the foot of Mount Olympus: A theory on myth}

beneath the surface of the story. The art of reading the text is to find the resemblance of truth through the myth. However, the real art lies in the understanding of the metaphor.

One's personal horizon must fuse with the horizon that the text proposes. This happens in the kerygma. The kerygma is understandable as kerygma only when the self-understanding awakened by it is recognized to be a possibility of human self-understanding and thereby becomes the call to decision.

A metaphor works when the literal meaning is not acceptable. This very fact confirms the kerygmatic character of the Christ myth. The content is not historical or universal truths but is a personal address in a concrete situation. The kerygma of the myth appears in a form moulded by an individual's understanding of one's own existence or by one's interpretation of that understanding. Correspondingly, it is understandable only to one who is able to recognize the kerygma as a word addressed to one in one's situation - to recognize it immediately only as a question asked or as a demand made.

Today more and more readers, scholars as well as members of the faith community and the church, realize that the gospel should not be literally interpreted. Thus, the text as a whole has a metaphorical twist. It is myth that must be interpreted. The metaphors used in the gospel narratives are archetypes in the subconscious of human beings. Reading these stories allows one to realize on a subconscious level the correspondence with the archetypes that exist in the subconscious of humans. Thus, the mythical representation through the metaphor of the text communicates with the archetype in the reader's subconscious and that enables the reader see (experience).

To understand the gospel is thus to see. To see means to look beyond the story and to let your subconscious revive the myth. When the myth revives, it facilitates your entrée into an experience with God. The myths represented in the narratives of antiquity are the stories that one needs for living. They are myths of life and death and new beginnings, of nobodies who turn into heroes, of martyrs and conquerors. The gospel is a narrative that invites you to join, to integrate your life with the storyline of the text. Once you have joined, the metaphor opens up and through the myth hidden in it, you enter into an experience with God. That is what reading the text is about. Thus, while myths have their limitations and their dangers, they cannot be discarded. They are necessary ciphers for evoking an awareness of the deepest realities in human experience.

Somewhere in the past, it seems that the church as institute has lost this experience. The church historized the Christ myth. The fact that myths 
generally operate on a different level of reality was overlooked. In recent times, when an attempt was undertaken by the scholarly community to compare these myths with the historical facts, the attempt failed, because myths did not pretend to be history. They are rather experiences of faith. A sermon on a Sunday as part of a service, as I understand it, is thus not supposed to be a lesson in history, biblical geography, text-critical remarks, literature analysis, or in first century Mediterranean sociology, but the congregation's meeting-experience with God. The preacher/ liturgist is the facilitator in translating the myth into the idiom that your audience can relate to. The service is thus not about knowing, facts or sharing information, but it is about an experience mediated and facilitated by the liturgist through song, prayer, myth, bread, wine, and baptism so that the audience can experience God in faith. I am not convinced that the members and leaders of the institutionalized church are currently willing to accept such an insight.

As part of the faith community, I know that God cannot be met in dogmas, creeds, and teachings about God. God can only be met in an experience with God. Myth is a phenomenon that can reveal the subconscious and that can help one to experience it. This experience of myth provides an entrée to the experience of God.

\section{Works Consulted}

Armstrong, K 1999. A history of God. London: Vintage.

Aune, D E 1990. Heracles and Christ: Heracles imagery in the Christology of early Christianity, in Balch, D L, Ferguson, E \& Meeks, W A (eds), Greeks, Romans, and Christians: Essays in honor of Abraham, J Malherbe, 2-19. Minneapolis, MN: Fortress Press.

Bidney, D 1953. The concept of myth, in Bidney 1953: 286-326.

Bidney, D (ed) 1953. Theoretical anthropology. New York: Columbia University Press.

Boskovic, A 2001a. Ritual and power. Unpublished lecture on myth (1). Department of Social Anthropology, University of the Witwatersrand.

Boskovic, A 2001b. Ritual and power. Unpublished lecture on myth (2). Department of Social Anthropology, University of the Witwatersrand.

Brongers, H A 1982. De literatuur van het Oude Testament, in Van der Woude (ed), Bijbels Handboek. 2a Het Oude Testament, 172-274. Kampen: Kok.

Campbell, J 1972. Myths to live by. New York: Bantam.

Corsar, P K, MacKinnon, N, Reid, A, Rooney, J \& Smith, R S 1977. Discovering the Greeks. London: Edward Arnold.

Crossan, J D 1998. The birth of Christianity: Discovering what happened in the years immediately after the execution of Jesus. New York: HarperSanFrancisco.

Dinkler, E 1982. Myth in the NT, in Interpreter's Dictionary of the Bible, Vol 3. Nashville, TN: Abingdon Press. 
Eliade, M 1961. Images and symbols: Studies in religious symbolism, tr by P Mairet. London: Harvill.

Fontenrose, J 1959. Python: A study of Delphic myth and its origins. Berkeley, CA: University of California Press.

Frankfort, $\mathrm{H}$ \& Frankfort H A 1946. Conclusion, in The intellectual adventure of ancient man: An essay on speculative thought in the Ancient Near East. Chicago, IL: The University of Chicago Press.

Frankfort, H \& Frankfort, H A 1946. Introduction, in The intellectual adventure of ancient man: An essay on speculative thought in the Ancient Near East. Chicago, IL: The University of Chicago Press.

Gaster, T H 1982. s v Myth: Mythology. IDB Vol 3. Nashville, TN: Abingdon Press.

Gaster, T H 1984. Myth and story, in Dundes, A (ed), Sacred narrative: Readings in the theory of myth, 110-136. Berkeley, CA: University of California Press.

Gay, W C 1992. Ricoeur on metaphor and ideology. Darshana International 32 (1), 59-70.

Harris, S L \& Platzner, G 1995. Classical mythology: Images and insights. London: Mayfield.

Honko, L 1984. The problem of defining myth, in Dundes, A (ed), Sacred narrative: Readings in the theory of myth, 41-52. Berkeley, CA: University of California Press.

Jung, C G [1949] 1894. The psychology of the child archetype, in Dundes, A (ed), Sacred narrative: Readings in the theory of myth, 244-255. Berkeley, CA: University of California Press.

Kerényi, C 1976. Dionysos: Archetypal image of indestructible life, tr by R Manheim. London: Routledge \& Kegan Paul.

Klapwijk, J 1977. Dialektiek der verlichting. Amsterdam: Van Gorcum.

Koskenniemi, E 1998. Apollonius of Tyana. JBL 117(3), 455-457.

Mack, B L 1995. Who wrote the New Testament?: The making of the Christian myth. San Francisco, CA: HarperSanFrancisco.

Mann, F 2002. Ernst Cassirer and "primeval stupidity." http://www.buildfreedom.com/tl/ tl1071.html

McGrath, A E 1990. The genesis of doctrine: A study in the foundation of doctrinal criticism. Oxford: Basil Blackwell.

Megal, W D 1979. The function of myth and symbol in the psyche: A critical evaluation and comparison of the contributions of Simund Freud, Carl Jung, and Mircea Eliade toward the psychological study of religion. PhD Dissertation, Berkeley, California.

Meyer, W F, Moore, C \& Viljoen, H G 1988. Persoonlikheidsteorieë - van Freud tot Frankl. Johannesburg: Lexicon.

Niditch, S 1996. Oral world and written word: Ancient Israelite literature. Louisville, KY: Westminster John Knox.

Noth, M 1966. The Old Testament world. London: Adam \& Charles Black.

Pettazzoni, R 1984. The truth of myth, in Dundes, A (ed), Sacred narratives:

Readings in the theory of myth, 98-109. Berkeley, CA: University of California Press.

Schultz, W 2000. Cassirer and Langer on myth: An introduction. New York: Garland Publishing.

Segal, R A 1998. Jung on mythology. London: Routledge. 
Segal, R A 1999. Theorizing about myth. Amherst, MA: University of Massachusetts Press.

Smith, M 1971. Prolegomena to a discussion of aretalogies, divine men, the gospels and Jesus. JBL 90, 174-199.

Stewart, D 1971. The pyramids and sphinx. New York: Newsweek.

Theissen, G 1999. A theory of primitive Christian religion. London: SCM.

Tigue, J W 1994. The transformation of consciousness in myth: Integrating the thought of Jung and Campbell. New York: Peter Lang.

Turner, V 1969. The ritual process: Structure and anti-structure. Ithaca, NY: Cornell University Press.

Van Aarde, A G 2000. Jesus and Perseus against the background of common Greco-Roman thinking. Acta Patristica et Bizantina 11, 177-196.

Van Aarde, A G 2001. Fatherless in Galilee: Jesus as child of God. Harrisburg, PA: Trinity.

Van Niekerk, E 1996. Paradigms of mind: Personality perspectives in context. Johannesburg: Thomson.

Vriezen, Th C 1970. An outline of Old Testament theology. Oxford: Basil Blackwell. 